\title{
Thorpe-Ingold Effect on Photoinduced Electron Transfer of Dialkylsilylene-Spaced Divinylarene Copolymers Having Alternating Donor and Acceptor Chromophores
}

\author{
Mei-Yu Yeh, ${ }^{\dagger}$ Hsin-Chieh Lin, ${ }^{\dagger}$ Tsong-Shin Lim,,${ }^{\S}$ Shern-Long Lee, ${ }^{\dagger}$ Chun-hsien Chen, ${ }^{\dagger}$ \\ Wunshain Fann, and Tien-Yau Luh*,
}

Department of Chemistry, National Taiwan University, Taipei, Taiwan 106, Department of Physics, Tunghai University, Taichung, Taiwan 407, and Institute of Atomic and Molecular Sciences, Academia Sinica, Taipei, Taiwan 106

Received October 2, 2007; Revised Manuscript Received October 22, 2007

\begin{abstract}
Dialkylsilylene-spaced divinylarene copolymers having alternating donor and acceptor chromophores are designed and synthesized. The rates of photoinduced electron transfer (PET) depend on the nature of the substituent on silicon. A replacement of the methyl substituent by the bulky isopropyl group has been shown to enhance the rate of PET. The results are rationalized in terms of the Thorpe-Ingold effect, which would bring the neighboring donor and acceptor chromophores in closer proximity. The STM images of the isopropyl-substituted copolymers are more folded than those of the methyl-substituted analogues, and these results are consistent with the outcome of photophysical studies of these copolymers.
\end{abstract}

\section{Introduction}

Replacement of two geminal hydrogen atoms on a carbon tethering chain connecting two reacting centers by two alkyl substituents has been known to lead to conformational equilibrium changes which would bring the two reacting centers in close proximity and the reactivity is thus enhanced. ${ }^{1}$ Such geminal disubstitution effect, known as Thorpe-Ingold effect, has been widely applied in organic syntheses. ${ }^{1}$ This concept has been briefly explored for the conformational investigations of peptides ${ }^{2}$ and polymers. ${ }^{3}$ Alternating silylene-conjugated chromophore copolymers $\mathbf{1}^{4}$ have been shown to exhibit a range of interesting photophysical properties, such as intrachain chromophore-chromophore aggregation, ${ }^{5}$ light harvesting and fluorescence resonance energy transfer (FRET), ${ }^{6}$ photoinduced electron transfer, ${ }^{7}$ and transfer of chiroptical properties. ${ }^{8}$ The folding nature of $\mathbf{1}$ may be indispensable to dictate these photophysical properties. The origin of this folding character may arise from the conformational equilibrium of divinylsilane moiety in $\mathbf{1}$ (eq 1).

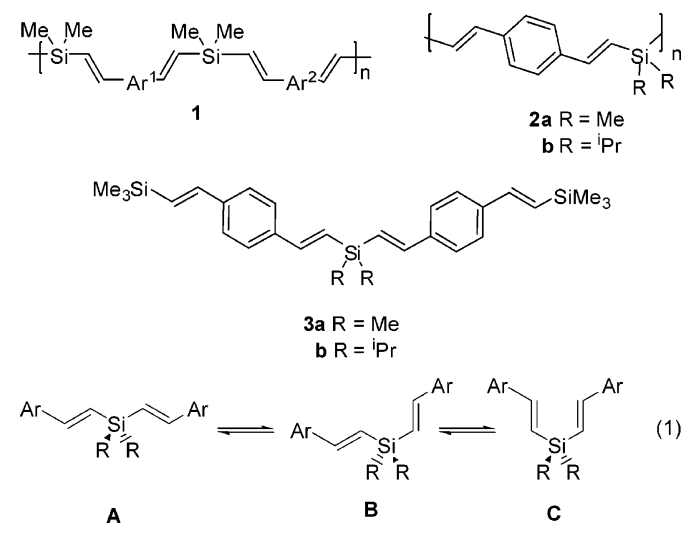

$\dagger$ National Taiwan University.

$\S$ Tunghai University.

$\doteqdot$ Academia Sinica.
It seems likely that conformations $\mathbf{B}$ and $\mathbf{C}$ might contribute significantly to the folding of $\mathbf{1}$. The relative populations of these conformers would depend on the nature of the substituent $\mathrm{R}$. Copolymer $\mathbf{1}$ would be more folded when $\mathrm{R}$ is a bulkier isopropyl group than when $\mathrm{R}$ is a methyl. Indeed, we recently found that emissions at longer wavelengths for $\mathbf{2 b}$ is significantly enhanced than those for $\mathbf{2 a} .^{5 b}$ Two kinds of chromophorechromophore interactions have been proposed. Through space interaction between non-neighboring chromophores would be responsible for the emission of $\mathbf{2}$ in the blue light region. Alternatively, the contribution from conformer $\mathbf{C}$ would bring two neighboring chromophores in close proximity so that interactions between these chromophores would lead to emission around $390 \mathrm{~nm}$. The emission in this region was also found in dimers 3.

It is well documented that the efficacies of photoinduced electron transfer (PET) processes depend on the distance between donor and acceptor chromophores. ${ }^{9}$ We have recently shown that PET occurred efficiently in dimethylsilylene-spaced divinylarene copolymers $\mathbf{1}$ having alternating donor and acceptor chromophores. ${ }^{7}$ Through-space interaction between neighboring chromophores has been suggested. ${ }^{7,10}$ It is envisaged that a replacement of the methyl substituent by the bulky isopropyl group would bring the neighboring donor and acceptor chromophores in closer proximity. In this paper, we report the first example on Thorpe-Ingold effect on the rates of electrontransfer process in silylene-spaced divinylarene copolymers 4 and $\mathbf{5}$ having alternating donor and acceptor chromophores.

\section{Results and Discussion}

Synthesis. Polymers $\mathbf{4}$ and $\mathbf{5}$ contain divinylene-terphenylene and terphenylene-tetravinylene, respectively, as the fluorophores and aminostyrene as the quencher were designed and synthesized. Silylene-spaced copolymers $\mathbf{4 a}$ and $\mathbf{4 b}$ were obtained by the rhodium-catalyzed hydrosilylation ${ }^{5-8}$ of bis(alkyne) 6 with bis(silanes) 7 (eq 2). Copolymers 5 were prepared similarly from $\mathbf{8}$ with $\mathbf{9}$ (eq 3). The details for the preparation of starting alkynes $\mathbf{6}^{7}$ and $\mathbf{8}^{7}$ and silanes $\mathbf{7}$ and $\mathbf{9}$ are described in the Experimental Section. 

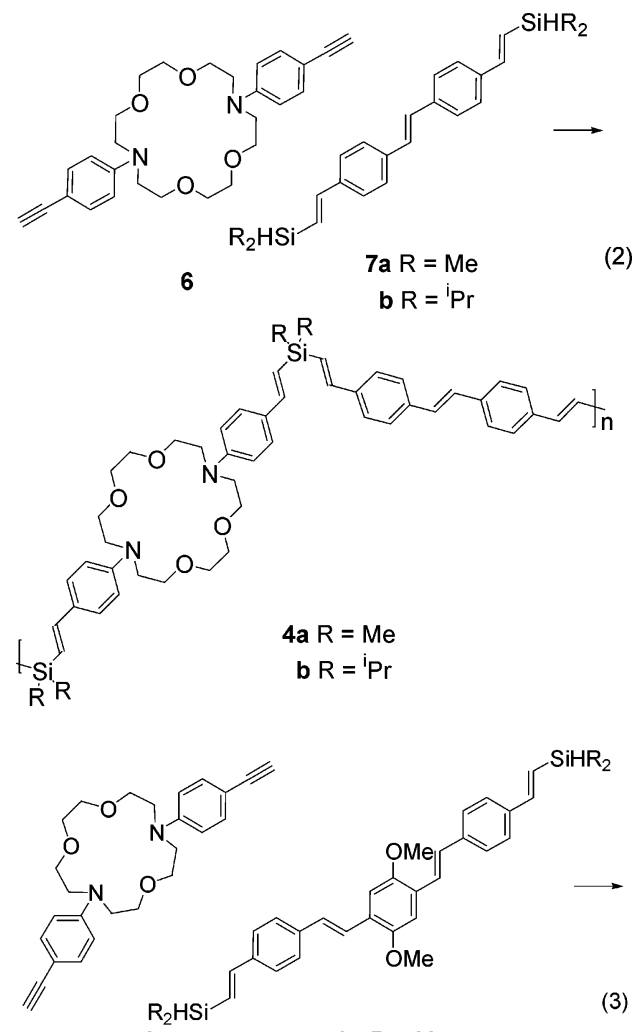

(3)

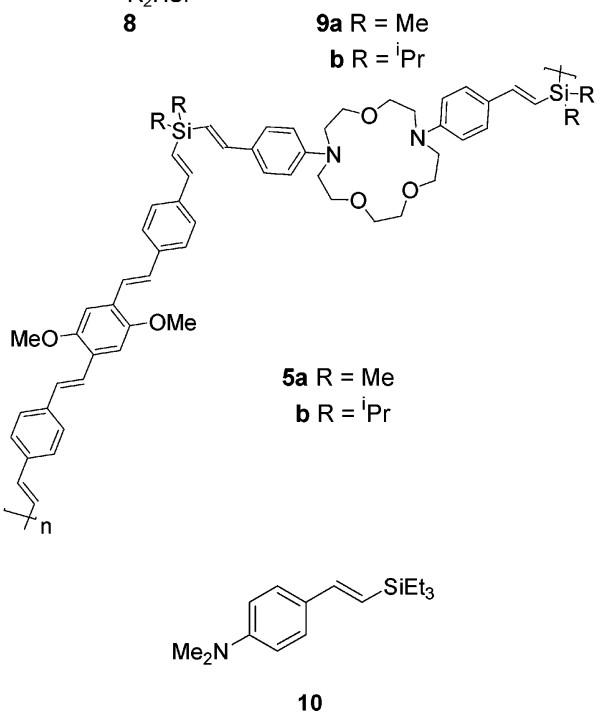

Photophysical Properties. The absorption spectra of $\mathbf{4}$ and 5 and the corresponding monomers (or model compound) 7, 9, and $\mathbf{1 0}$ are shown in Figure 1. As expected, there is no difference in the absorption spectra between the methyl-substituted and the isopropyl-substituted monomers and polymers. The emission spectra of these compounds are shown in Figure 2. These photophysical properties together with the oxidation potentials of these compounds are summarized in Table 1 and the frontier orbital energies were thus estimated.

Upon excitation at $355 \mathrm{~nm}$, both $7 \mathbf{a}$ and $7 \mathbf{b}$ in $\mathrm{CH}_{2} \mathrm{Cl}_{2}$ showed emission maxima at 390 and 410 with quantum yields 0.91 . The fluorescence of $\mathbf{4 a}$ and $\mathbf{4 b}$ in $\mathrm{CH}_{2} \mathrm{Cl}_{2}$ at 390 and $410 \mathrm{~nm}$ were very weak, and the corresponding quantum yields were 0.06 and 0.05 , respectively. When the measurements were carried in cyclohexane, the quantum yields for $\mathbf{4 a}$ and $\mathbf{4 b}$ were 0.49 and 0.14 , respectively. The emission of $9 \mathbf{a}$ and $\mathbf{9 b}$ in $\mathrm{CH}_{2}-$ $\mathrm{Cl}_{2}$ appeared at 469 and $495 \mathrm{~nm}$ upon excitation at $410 \mathrm{~nm}$ and the quantum yields were 0.71 and 0.70 , respectively. Again, the luminescence of $\mathbf{5 a}$ and $\mathbf{5 b}$ in $\mathrm{CH}_{2} \mathrm{Cl}_{2}$ appeared at the same
Table 1. Photophysical Properties of Polymers 4 and 5 and the Corresponding Monomers 7, 9, and 10 and the Frontier Orbital Energies of the Corresponding Chromophores

\begin{tabular}{llclccc}
\hline & $\begin{array}{c}\lambda_{\max } \\
(\mathrm{nm})^{a}\end{array}$ & $\begin{array}{c}\lambda_{\mathrm{em}} \\
(\mathrm{nm})^{a}\end{array}$ & \multicolumn{1}{c}{$\Phi^{a, b}$} & $\begin{array}{c}E_{\mathrm{ox}^{c}} \\
(\mathrm{~V})\end{array}$ & $\begin{array}{c}\mathrm{HOMO}^{d} \\
(\mathrm{eV})\end{array}$ & $\begin{array}{c}\mathrm{LUMO}^{e} \\
(\mathrm{eV})\end{array}$ \\
\hline $\mathbf{4 a}$ & 338 & 390,410 & $0.06(0.49)$ & & & \\
$\mathbf{4 b}$ & 338 & 390,410 & $0.05(0.14)$ & & & \\
$\mathbf{5 a}$ & 334,411 & 469,495 & $0.51(0.68)$ & & & \\
$\mathbf{5 b}$ & 335,409 & 469,495 & $0.12(0.55)$ & & & \\
$\mathbf{7 a}$ & 342,355 & 390,410 & 0.91 & 0.82 & -5.62 & -2.44 \\
$\mathbf{7 b}$ & 342,355 & 390,410 & 0.91 & 0.82 & -5.62 & -2.44 \\
$\mathbf{9 a}$ & 337,411 & 469,495 & 0.71 & 0.46 & -5.26 & -2.56 \\
$\mathbf{9 b}$ & 338,409 & 469,495 & 0.70 & 0.46 & -5.26 & -2.59 \\
$\mathbf{1 0}$ & 308 & 378 & 0.03 & 0.18 & -4.98 & -1.57
\end{tabular}

${ }^{a}$ Measured in $\mathrm{CH}_{2} \mathrm{Cl}_{2}$ unless otherwise specified. ${ }^{b}$ Using coumarin 1 in EtOAc $(\Phi=0.99)$ as the standard. The numbers in the bracket are the quantum yield measured in cyclohexane. ${ }^{c}$ Oxidation potentials determined by cyclicvoltammetry using $0.1 \mathrm{M} \mathrm{Bu}_{4} \mathrm{NPF}_{6}$ as electrolyte in $\mathrm{CH}_{2} \mathrm{Cl}_{2}$ with $\mathrm{Pt}$ working electrode, $\mathrm{Pt}$ wire counter electrode, and $\mathrm{Ag} / \mathrm{AgNO}_{3}$ reference electrode. ${ }^{d}$ Estimated by $E_{\mathrm{ox}} \mathrm{vs} \mathrm{Fc} / \mathrm{Fc}^{+} .{ }^{e}$ Estimated by $\mathrm{HOMO}$ and optical band gap from the absorption spectra.

Table 2. Fluorescence Lifetime $(\tau)$ and the Reciprocal of the Fluorescence Lifetime $\left(k_{\mathrm{s}}\right)$ of $7 \mathrm{a}, \mathrm{b}$ and $9 \mathrm{a}, \mathrm{b}$ in $\mathrm{CH}_{2} \mathrm{Cl}_{2}$ and Cyclohexane at Ambient Temperature

\begin{tabular}{|c|c|c|c|}
\hline substrate $^{a}$ & solvent & $\begin{array}{c}\text { fluorescence } \\
\text { lifetime } \\
\tau(\mathrm{ps})\end{array}$ & $\begin{array}{l}\text { reciprocal of the } \\
\text { fluorescence lifetime } \\
\quad k_{\mathrm{s}}\left(\mathrm{ns}^{-1}\right)\end{array}$ \\
\hline \multirow[t]{2}{*}{$7 a(7 b)$} & $\mathrm{CH}_{2} \mathrm{Cl}_{2}$ & 941 & 1.1 \\
\hline & cyclohexane & 880 & 1.1 \\
\hline \multirow[t]{2}{*}{$9 \mathbf{a}(9 \mathrm{~b})$} & $\mathrm{CH}_{2} \mathrm{Cl}_{2}$ & 1400 & 0.7 \\
\hline & cyclohexane & 1200 & 0.8 \\
\hline
\end{tabular}

$a$ The concentrations $\left(\sim 10^{-5} \mathrm{M}\right)$ for 7 and $9 .{ }^{b}$ Time-resolved fluorescence lifetimes are estimated by exponential fitting of decay curve $\left(R^{2}=\right.$ $0.996-0.999)$

wavelengths with quantum yields 0.51 and 0.12 , respectively. The quantum yields for the emission of $\mathbf{5 a}$ and $\mathbf{5} \mathbf{b}$ in cyclohexane were 0.68 and 0.55 , respectively.

As expected, the quantum yields of the polymers were much smaller than those of the monomeric compounds when $\mathrm{CH}_{2} \mathrm{Cl}_{2}$ was used as the solvent. Photoinduced electron-transfer between the aminostyrene and oligophenylene-vinylene chromophores may readily take place in this polar solvent. It is particularly noteworthy that the decrease in quantum yields were more prominent for polymers $\mathbf{4 b}$ and $\mathbf{5 b}$ having isopropyl substituent on silicon than those for $\mathbf{4 a}$ and $\mathbf{5 a}$ with methyl substituent. Apparently, Thorpe-Ingold effect may dictate the conformation of $\mathbf{4 b}$ and $\mathbf{5 b}$ to bring the two neighboring chromophores in conformation $\mathrm{C}$ (eq 1 ). As such, polymers $\mathbf{4 b}$ and $\mathbf{5 b}$ might be more folded and the chances for the two chromophores to meet each other in space might be larger and the electron-transfer process might be facilitated.

As can be seen from Table 1, the quantum yields in $\mathbf{4}$ were more significantly reduced than those in $\mathbf{5}$ in comparison with the quantum yields of the corresponding monomeric model compounds $\mathbf{7}$ and $\mathbf{9}$, respectively.

The emissions of polymers $\mathbf{4}$ and $\mathbf{5}$ were very much solvent dependent. Presumably, the conformation of polymers $\mathbf{4}$ and $\mathbf{5}$ would also depend on the nature of the solvent. It is particularly interesting to note that the lifetime of $\mathbf{5} \mathbf{a}$ was comparable to that of 9a in cyclohexane. This result suggested that there might be no electron transfer in 5a in this nonpolar solvent. On the other hand, the emission was somewhat quenched in $\mathbf{5 b}$ even in cyclohexane when isopropyl substituent on silicon was incorporated. It seems likely that the bulky isopropyl substituent may bring the neighboring chromophores in closer proximity so that electron transfer might facilely take place. 

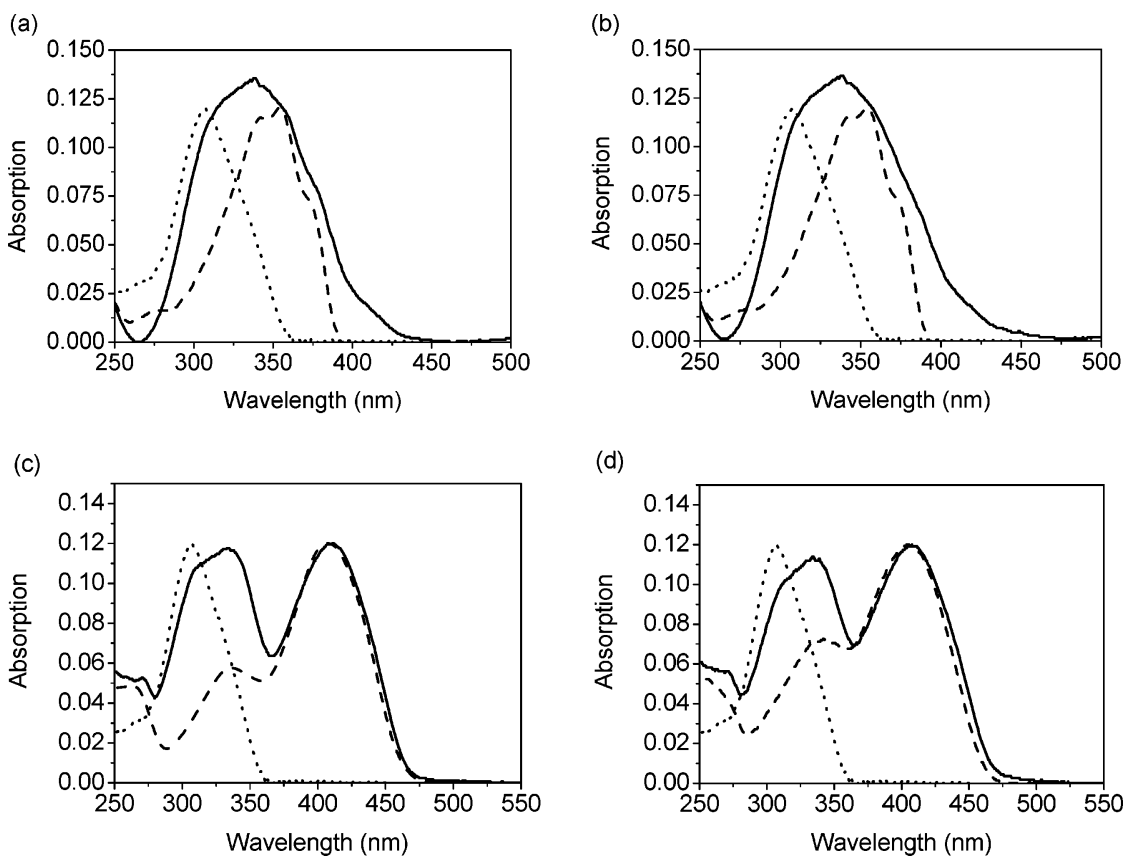

Figure 1. Absorption spectra of polymers 4 or $\mathbf{5}$ (solid line) and the corresponding monomeric model compounds $\mathbf{7}$ or $\mathbf{9}$ (dashed line) and $\mathbf{1 0}$ (dotted line) in $\mathrm{CH}_{2} \mathrm{Cl}_{2}$. Key: (a) $\mathbf{4 a}, \mathbf{7 a}$, and $\mathbf{1 0}$; (b) $\mathbf{4 b}, \mathbf{7 b}$, and $\mathbf{1 0}$; (c) $\mathbf{5 a}, \mathbf{9 a}$, and $\mathbf{1 0}$; (d) $\mathbf{5 b}, \mathbf{9 b}$, and $\mathbf{1 0}$ (concentration: $1 \times 10^{-5} \mathrm{M}$ ).
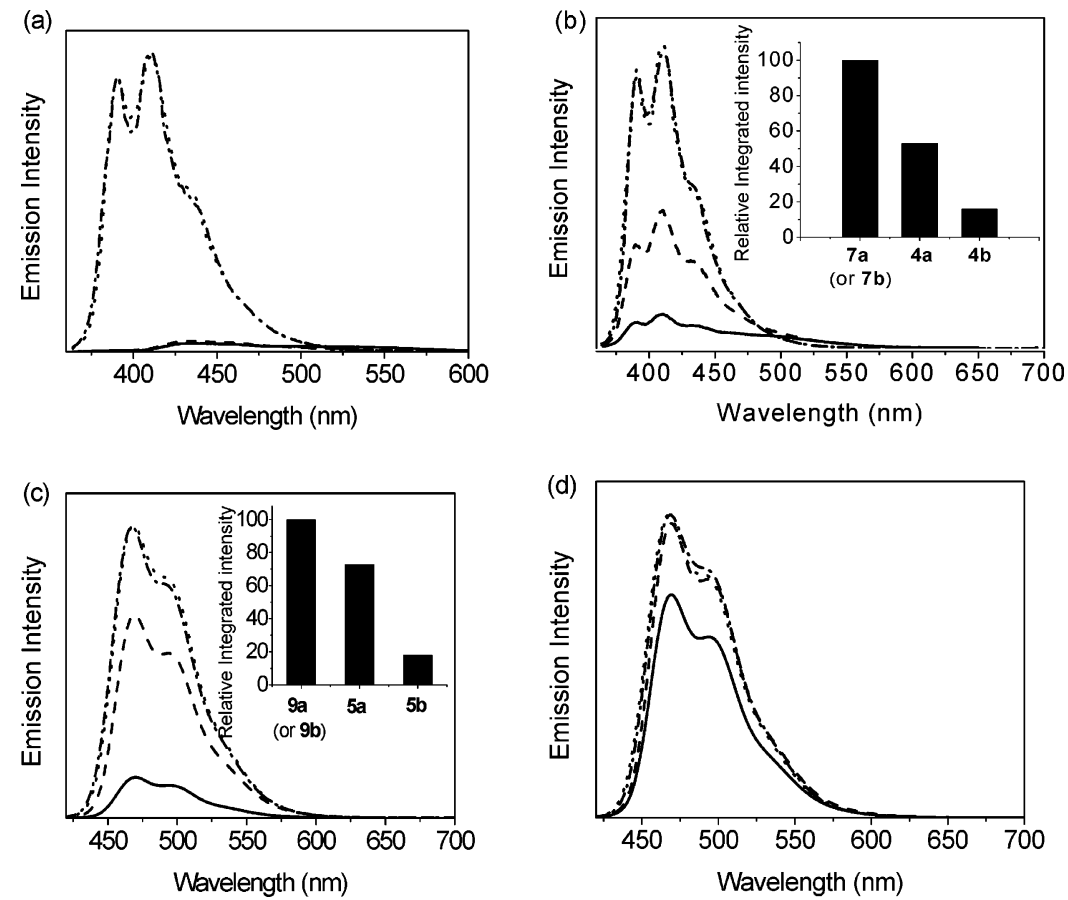

Figure 2. Emission spectra of $\mathbf{4 a}$ (dashed line), $\mathbf{4 b}$ (solid line), $\mathbf{7 a}$ (dashed-dotted line), and $\mathbf{7 b}$ (dotted line) in (a) $\mathrm{CH}_{2} \mathrm{Cl}_{2}$ and (b) $c y c l o h e x a n e$. Inset: the relative ratios of the integrated emission intensities of $\mathbf{4}$ and 7. $\left(\lambda_{\mathrm{ex}}=355 \mathrm{~nm}\right)$. Emission spectra of 5a (dashed line), 5b (solid line), 9a (dashed-dotted line), and $\mathbf{9 b}$ (dotted line) in (c) $\mathrm{CH}_{2} \mathrm{Cl}_{2}$. Inset: the relative ratios of the integrated emission intensities of $\mathbf{5}$ and $\mathbf{9}$; (d) cyclohexane $\left(\lambda_{\mathrm{ex}}=410 \mathrm{~nm}\right)$ (concentration: $\left.1 \times 10^{-5} \mathrm{M}\right)$.

Time-Resolved Fluorescence Spectroscopy. Femtosecond laser equipped with streak camera was employed to measure the time-resolved spectra of fluorescence decay in polymers $\mathbf{4}$, 5 and the corresponding monomers 7 and $\mathbf{9}$ in $\mathrm{CH}_{2} \mathrm{Cl}_{2}$ and in cyclohexane. The fluorescence decay profiles of $\mathbf{4 a}, \mathbf{4 b}$ and $\mathbf{5 a}$, 5b in $\mathrm{CH}_{2} \mathrm{Cl}_{2}$ and in cyclohexane are shown in Figure 3. The fluorescence decay lifetimes $(\tau)$ were estimated by oneexponential curve-fittings for monomers 7 and 9 and twoexponential curve-fittings for polymers $\mathbf{4}$ and $\mathbf{5}$, unless otherwise specified. The results are summarized in Tables 2 and 3.

The fluorescence lifetimes, $\tau$, in general, were shorter for $\mathbf{4}$ than those for 5; hence the charge separation rates $k_{\mathrm{CS}}$ for $\mathbf{4}$ were larger than those for $\mathbf{5}$. In addition, shorter $\tau$ 's and larger $k_{\mathrm{CS}}$ 's were observed for isopropyl-substituted polymers $\mathbf{4 b}$ and $\mathbf{5 b}$ than those for methyl-substituted analogues $\mathbf{4 a}$ and $\mathbf{5 a}$. As expected, the $\tau$ 's were shorter and $k_{\mathrm{CS}}$ 's were faster in $\mathrm{CH}_{2} \mathrm{Cl}_{2}$ than those in cyclohexane.

As can be seen from Table 3, two parameters were used to fit the fluorescence decay curves. This observation suggested that there might be two different modes of electron-transfer processes in polymers $\mathbf{4}$ and $\mathbf{5}$. The shorter lifetimes $\tau_{1}$ 's, the faster $k_{C S 1^{\prime}} \mathrm{s}$, and the higher charge separation yields $\Phi_{\mathrm{CS} 1}$ may arise from the interaction of two neighboring chromophores separated by a silylene moiety. We have shown that silylene- 

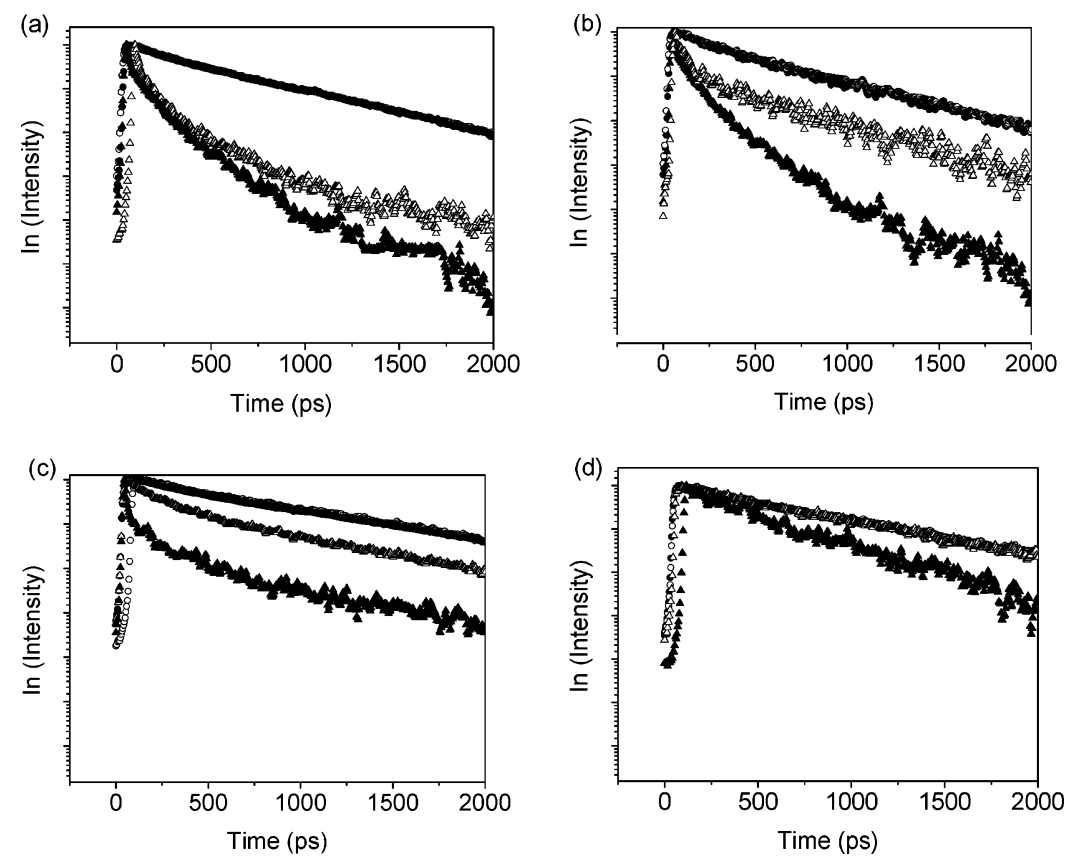

Figure 3. Time-resolved fluorescence decays of $\mathbf{4 a}$ (open up triangle), $\mathbf{4 b}$ (solid up triangle), $\mathbf{7 a}$ (open circle), and $\mathbf{7 b}$ (solid circle) in (a) $\mathrm{CH}_{2} \mathrm{Cl}_{2}$; (b) cyclohexane $\left(\lambda_{\mathrm{ex}}=375 \mathrm{~nm}\right.$ and monitored at $400 \mathrm{~nm}$ ). Time-resolved fluorescence decays of $\mathbf{5 a}$ (open up triangle), $5 \mathbf{b}$ (solid up triangle), 9a (open circle), and $9 \mathbf{b}$ (solid circle) in (c) $\mathrm{CH}_{2} \mathrm{Cl}_{2}$; (d) cyclohexane $\left(\lambda_{\mathrm{ex}}=410 \mathrm{~nm}\right.$ and monitored at $475 \mathrm{~nm}$ ) (concentration: $1 \times 10^{-5} \mathrm{M}$ ).

Table 3. Fluorescence Lifetime $(\tau)$, Charge-Transfer Rate Constant $\left(k_{\mathrm{cs}}\right)$ and Charge-separation Yield $\left(\Phi_{\mathrm{cs}}\right)$ of $4 \mathrm{a}, \mathrm{b}$ and $5 \mathrm{a}, \mathrm{b}$ in $\mathrm{CH}_{2} \mathrm{Cl}_{2}$ and Cyclohexane at Ambient Temperature ${ }^{11}$

\begin{tabular}{|c|c|c|c|c|c|c|c|}
\hline \multirow[b]{2}{*}{ substrate $^{a}$} & \multirow[b]{2}{*}{ solvent } & \multicolumn{2}{|c|}{ fluorescence lifetime ${ }^{b} \tau(\mathrm{ps})$} & \multicolumn{2}{|c|}{ charge-transfer rate $k_{\mathrm{cs}}\left(\mathrm{ns}^{-1}\right)^{d}$} & \multicolumn{2}{|c|}{ charge-separation yield $\Phi_{\mathrm{cs}}$} \\
\hline & & $\tau_{1}$ & $\tau_{2}$ & $k_{\mathrm{cs} 1}$ & $k_{\mathrm{cs} 2}$ & $\Phi_{\mathrm{cs} 1}$ & $\Phi_{\mathrm{cs} 2}$ \\
\hline \multirow[t]{2}{*}{$4 a$} & $\mathrm{CH}_{2} \mathrm{Cl}_{2}$ & $49(0.80)$ & $463(0.20)$ & 19.0 & 1.1 & 0.95 & 0.51 \\
\hline & cyclohexane & $91(0.56)$ & $857(0.44)$ & 9.9 & 0.03 & 0.89 & 0.03 \\
\hline \multirow[t]{2}{*}{$4 b$} & $\mathrm{CH}_{2} \mathrm{Cl}_{2}$ & $29(0.83)$ & $263(0.17)$ & 33.0 & 2.7 & 0.97 & 0.72 \\
\hline & cyclohexane & $54(0.71)$ & $303(0.29)$ & 17.0 & 2.2 & 0.94 & 0.66 \\
\hline $5 \mathbf{a}$ & $\begin{array}{l}\mathrm{CH}_{2} \mathrm{Cl}_{2} \\
\text { cyclohexane }\end{array}$ & $192(0.50)$ & $\begin{array}{l}1300(0.50) \\
1198^{c}(1.00)\end{array}$ & 4.5 & 0.03 & 0.86 & 0.04 \\
\hline \multirow[t]{2}{*}{$5 \mathbf{b}$} & $\mathrm{CH}_{2} \mathrm{Cl}_{2}$ & $48(0.80)$ & $854(0.20)$ & 20.0 & 0.45 & 0.97 & 0.40 \\
\hline & cyclohexane & $358(0.37)$ & $878(0.63)$ & 2.0 & 0.3 & 0.70 & 0.27 \\
\hline
\end{tabular}

${ }^{a}$ The concentrations $\left(\sim 10^{-5} \mathrm{M}\right)$ for $\mathbf{4}$ and $\mathbf{5} .{ }^{b}$ Time-resolved fluorescence lifetimes are estimated by exponential fitting of decay curve $\left(R^{2}=0.97-\right.$ 0.99). The numbers in the bracket are the relative weight of different time constants. ${ }^{c}$ One exponential fitting. ${ }^{d} k_{\mathrm{cs}}=\tau^{-1}-k_{\mathrm{s}}$ where $\tau$ is corresponding fluorescence lifetime and $k_{\mathrm{s}}$ is the reciprocal of the fluorescence lifetime of the corresponding monomer (ref 11).

(a)

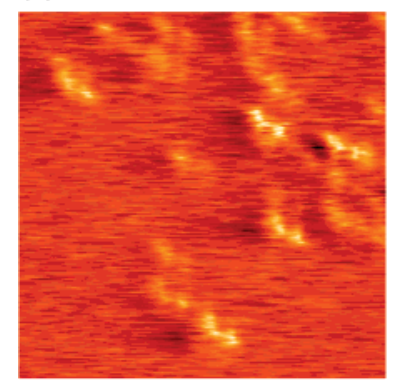

(b)

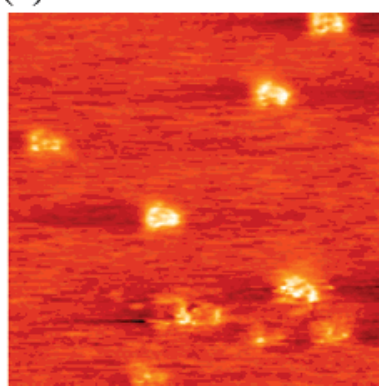

Figure 4. STM image of (a) 4a and (b) 4b. Conditions: (a) image size, $27 \times 27 \mathrm{~nm}, E_{\text {bias }} 0.80 \mathrm{~V}$, $i_{\text {tunneling }} 20 \mathrm{pA}$; (b) image size, $27 \times 27$ $\mathrm{nm}, E_{\text {bias }} 0.50 \mathrm{~V}, i_{\text {tunneling }} 20 \mathrm{pA}$.

spaced divinylarene copolymers are highly folded. Accordingly, there is possibility that two non-neighboring chromophores may meet each other through space. Such folding may lead to a second type of interaction between chromophores and, therefore, a second set of longer $\tau_{2}$ 's, slower $k_{C S 2^{\prime}}$, and the smaller $\Phi_{\mathrm{CS}^{-}}$ was observed as depicted in Table 3.

Scanning Tunneling Microscopy. Scanning tunneling microscopy was employed to examine the morphology of polymer 4 on highly ordered pyrolyzed graphite (HOPG) surface and the results are shown in Figure 4. The images of $\mathbf{4 a}$ are fuzzier than those of $\mathbf{4 b}$, presumably due to the more fluxional conformation of $\mathbf{4 a}$ than that of $\mathbf{4 b}$. The methyl-substituted $\mathbf{4 a}$ exhibited a relatively loose and elongated feature with a length roughly about $4.3 \mathrm{~nm}$. On the other hand, the morphology of 4b appeared to be very different and the average diameter was $3.4 \mathrm{~nm}$. Apparently, the isopropyl group may provide a bulky environment to provoke the divinylsilane moieties in $\mathbf{4 b}$ to adopt conformation $\mathbf{C}$ (eq 1). As a result, the conformation for $\mathbf{4 b}$ would be expected to be in highly coiled structure. Such kind of coiled structure may lead strong interactions between chromophores in $\mathbf{4 b}$ and is seredipiously consistent with the photophysical results described above.

\section{Conclusions}

In summary, we have demonstrated the use of the concept of Thorpe-Ingold effect to direct the conformation of silylenespaced divinylarene copolymers. Since distance is known to play an important role in PET processes, the present investigation suggested that bulky substituent on silicon would bring the chromophores in closer proximity. Copolymers with bulky isopropyl substituent are more folded so that intrachain PET between these chromophores will become more prominent leading to more efficient fluorescence quenching. The results from the STM images appear to be consistent with the outcome 
of photophysical studies of these polymers. Further investigations on integration of light harvesting and electron transfer in a single polymer are in progress.

\section{Experimental Section}

General Data. Gel permeation chromatography (GPC) was performed on a Waters GPC machine using an isocratic HPLC pump (1515) and a refractive index detector (2414). THF was used as the eluent (flow rate $=1.0 \mathrm{mLmin}^{-1}$ ). Waters Styragel HR2, HR3, HR4 $(7.8 \times 300 \mathrm{~mm})$ were employed using polystyrene as standard $\left(M_{\mathrm{n}}\right.$ values range from 375 to $\left.3.5 \times 10^{6}\right)$. Absorption spectra and emission spectra were measured with Hitachi U-3310 and Hitachi F-4500 fluorescence spectrophotometers, respectively. Quantum yield was obtained using coumarin $\mathbf{1}$ in EtOAc as reference $(\Phi=0.99)$.

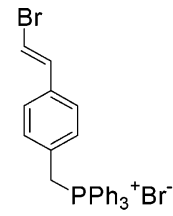

11

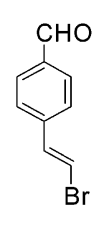

12
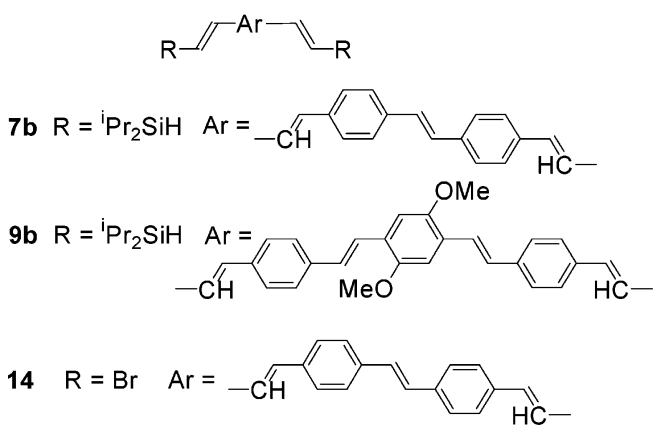

$15 \mathrm{R}=\mathrm{Br}$

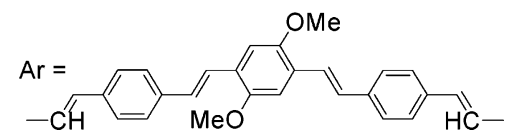

1,4'-Bis(2-bromovinyl)stilbene (14). To a mixture of $\mathbf{1 1}^{12}$ (2.80 g, $5.2 \mathrm{mmol})$ and $\mathbf{1 2}^{13}(1.08 \mathrm{~g}, 5.1 \mathrm{mmol})$ in EtOH $(90 \mathrm{~mL})$ was added NaOEt [prepared from sodium $(0.18 \mathrm{~g}, 7.8 \mathrm{mmol})$ in ethanol $(30 \mathrm{~mL})]$. The mixture was refluxed for $15 \mathrm{~h}$ and cooled to room temperature. Methanol was added, and the precipitate was collected. The solid was dissolved in toluene to which a trace amount of iodine was added. The mixture was refluxed for $24 \mathrm{~h}$. Solvent was removed in vacuo, and the residue was washed with hexane until washings were almost colorless. The residue was recrystallized from toluene to give $\mathbf{1 4}$ as a white solid $(1.69 \mathrm{~g}, 85 \%): \mathrm{mp} 89-90{ }^{\circ} \mathrm{C} ;{ }^{1} \mathrm{H}$ NMR $\left(400 \mathrm{MHz}, \mathrm{CDCl}_{3}\right): \delta 6.80(\mathrm{~d}, J=14.0 \mathrm{~Hz}, 2 \mathrm{H}), 7.08(\mathrm{~s}, 2 \mathrm{H})$, $7.10(\mathrm{~d}, J=14.0 \mathrm{~Hz}, 2 \mathrm{H}), 7.29(\mathrm{~d}, J=8.2 \mathrm{~Hz}, 4 \mathrm{H}), 7.47(\mathrm{~d}, J$ $=8.2 \mathrm{~Hz}, 4 \mathrm{H}) \cdot{ }^{13} \mathrm{C}$ NMR $\left(100 \mathrm{MHz}, \mathrm{CDCl}_{3}\right): \delta 106.5,126.3$, 126.8, 128.2, 135.1, 136.6, 137.0. IR (KBr): v 3068, 3007, 2921, $1704,1646,1503,1491,1405,984,956,935,884,785 \mathrm{~cm}^{-1}$. HRMS (FAB): calcd for $\mathrm{C}_{18} \mathrm{H}_{14}{ }^{79} \mathrm{Br}_{2}, 387.9462$; found, 387.9454 . Anal. Calcd for $\mathrm{C}_{18} \mathrm{H}_{14} \mathrm{Br}_{2}$ : C, 55.42; H, 3.62. Found: C, 55.39; H, 3.32.

1,4-Bis(4-(2-bromovinyl)styryl)-2,5-dimethoxybenzene (15). To a mixture of $\mathbf{1 1} \mathbf{1}^{12}(5.5 \mathrm{~g}, 10.3 \mathrm{mmol})$ and $\mathbf{1 3}(1.0 \mathrm{~g}, 5.1 \mathrm{mmol})$ in $\mathrm{EtOH}(90 \mathrm{~mL})$ was added $\mathrm{NaOEt}$ [prepared from sodium $(0.35$ $\mathrm{g}, 15.5 \mathrm{mmol})$ in ethanol $(60 \mathrm{~mL})]$. The mixture was refluxed for $15 \mathrm{~h}$ and cooled to room temperature. Methanol $(150 \mathrm{~mL})$ was added, and the resulting precipitate was collected. The solid was dissolved in toluene $(100 \mathrm{~mL})$, and the mixture was refluxed in the presence of a trace amount of iodine for 1 day. Solvent was removed in vacuo, and the residue was washed with hexane (300 $\mathrm{mL}$ ) until washings were almost colorless; the residue was then recrystallized from toluene to give compound $\mathbf{1 5}$ as a yellow solid
(2.25 g, 80\%): mp 189-190 ${ }^{\circ} \mathrm{C} .{ }^{1} \mathrm{H}$ NMR $\left(400 \mathrm{MHz}, \mathrm{CDCl}_{3}\right): \delta$ $3.94(\mathrm{~s}, 6 \mathrm{H}), 6.79$ (d, $J=14.0 \mathrm{~Hz}, 2 \mathrm{H}), 7.09$ (d, $J=16.4 \mathrm{~Hz}, 2$ $\mathrm{H}), 7.10(\mathrm{~d}, J=14.0 \mathrm{~Hz}, 2 \mathrm{H}), 7.13(\mathrm{~s}, 2 \mathrm{H}), 7.29(\mathrm{~d}, J=8.0 \mathrm{~Hz}$, $4 \mathrm{H}), 7.49$ (d, $J=8.0 \mathrm{~Hz}, 4 \mathrm{H}), 7.50(\mathrm{~d}, J=16.4 \mathrm{~Hz}, 2 \mathrm{H}) .{ }^{13} \mathrm{C}$ NMR (100 MHz, $\left.\mathrm{CDCl}_{3}\right): \delta 56.4,106.1,108.7,123.2,126.0,126.2$, $126.6,127.9,134.5,136.4,137.3,150.9$. IR (KBr): $v$ 3048, 2983 , 2917, 2856, 2811, 1597, 1561, 1509 1459, 1410, 1340, 1263, 1212, $1037,955,845,776,669 \mathrm{~cm}^{-1}$. HRMS (FAB): calcd $\mathrm{C}_{28} \mathrm{H}_{24} \mathrm{O}_{2}{ }^{79}-$ $\mathrm{Br}_{2}, 550.0143$; found, 550.0146. Anal. Calcd for $\mathrm{C}_{28} \mathrm{H}_{24} \mathrm{O}_{2} \mathrm{Br}_{2}$ : C, 60.89; H, 4.38. Found: C, 60.57; H, 4.40 .

1,4'-Bis[(2-diisopropylsilyl)vinyl]stilbene (7b). Under $\mathrm{N}_{2}$, to a solution of $14(0.39 \mathrm{~g}, 1.0 \mathrm{mmol})$ in THF $(30 \mathrm{~mL})$ cooled at $-78{ }^{\circ} \mathrm{C}$ was added slowly ${ }^{t} \mathrm{BuLi}(2.7 \mathrm{~mL}$ of $1.55 \mathrm{M}$ in pentane, $4.2 \mathrm{mmol}$ ). After this mixture was stirred for $30 \mathrm{~min}$ at $-78{ }^{\circ} \mathrm{C}$, chlorodiisopropylsilane $(0.4 \mathrm{~mL}, 2.1 \mathrm{mmol})$ was added, and the mixture was gradually warmed to room temperature, stirring was continued for $3 \mathrm{~h}$, and the reaction was quenched with $\mathrm{H}_{2} \mathrm{O}(3.0$ $\mathrm{mL})$. The aqueous layer was extracted with $\mathrm{Et}_{2} \mathrm{O}(3 \times 10 \mathrm{~mL})$, and the organic layer was washed with brine $(20 \mathrm{~mL})$, dried $\left(\mathrm{MgSO}_{4}\right)$, filtered, and evaporated in vacuo. The residue was chromatographed on $\mathrm{Et}_{3} \mathrm{~N}$-treated silica gel $\left(\mathrm{CH}_{2} \mathrm{Cl}_{2} /\right.$ hexane 1:4) to afford $\mathbf{7 b}$ as an oil $(0.37 \mathrm{~g}, 80 \%) .{ }^{1} \mathrm{H}$ NMR $\left(400 \mathrm{MHz}, \mathrm{CDCl}_{3}\right)$ : $\delta 1.05-1.16(\mathrm{~m}, 28 \mathrm{H}), 3.76-3.78(\mathrm{~m}, 2 \mathrm{H}), 6.43(\mathrm{dd}, J=19.0$, $4.7 \mathrm{~Hz}, 2 \mathrm{H}), 7.05$ (d, $J=19.0 \mathrm{~Hz}, 2 \mathrm{H}), 7.11$ (s, $2 \mathrm{H}), 7.45$ (d, $J$ $=8.3 \mathrm{~Hz}, 4 \mathrm{H}), 7.50(\mathrm{~d}, J=8.3 \mathrm{~Hz}, 4 \mathrm{H}) .{ }^{13} \mathrm{C} \mathrm{NMR}(100 \mathrm{MHz}$, $\left.\mathrm{CDCl}_{3}\right): \delta 10.9,18.7,126.4,126.6,126.7,128.1,137.0,137.4$, 146.9. IR (KBr): $v 2962,2917,2852,2325,1593,1462,1381 \mathrm{~cm}^{-1}$. HRMS (FAB): calcd for $\mathrm{C}_{30} \mathrm{H}_{44} \mathrm{Si}_{2}, 460.2982$; found, 460.2977 .

1,4-Bis(4-(2-diisopropylsilylvinyl)styryl)-2,5-dimethoxybenzene $(9 \mathrm{~b})$. Under $\mathrm{N}_{2}$, to a solution of $15(0.55 \mathrm{~g}, 1.0 \mathrm{mmol})$ in THF $(30 \mathrm{~mL})$ cooled at $-78{ }^{\circ} \mathrm{C}$ was added slowly ${ }^{t} \mathrm{BuLi}(2.7 \mathrm{~mL}$ of $1.55 \mathrm{M}$ in pentane, $4.2 \mathrm{mmol}$ ). After the reaction was stirred for $30 \mathrm{~min}$ at $-78{ }^{\circ} \mathrm{C}$, chlorodiisopropylsilane $(0.4 \mathrm{~mL}, 2.1 \mathrm{mmol})$ was added, and the mixture was gradually warmed to room temperature, stirring was continued for $3 \mathrm{~h}$, and the reaction was quenched with $\mathrm{H}_{2} \mathrm{O}(3.0 \mathrm{~mL})$. The aqueous layer was extracted with $\mathrm{Et}_{2} \mathrm{O}(3 \times 20 \mathrm{~mL})$, and the organic layer was washed with brine $(20 \mathrm{~mL})$, dried $\left(\mathrm{MgSO}_{4}\right)$, filtered, and evaporated in vacuo. The residue was chromatographed on $\mathrm{Et}_{3} \mathrm{~N}$-treated silica gel $\left(\mathrm{CH}_{2}-\right.$ $\mathrm{Cl}_{2} / n$-hexane $\left.1: 4\right)$ and the solid was recrystallized from pentane to afford $9 \mathrm{~b}$ as a yellow solid $(0.50 \mathrm{~g}, 81 \%)$ : $\mathrm{mp} 183-184{ }^{\circ} \mathrm{C} .{ }^{1} \mathrm{H}$ NMR (400 MHz, $\left.\mathrm{CDCl}_{3}\right): \delta 1.00-1.20(\mathrm{~m}, 28 \mathrm{H}), 3.75-3.77(\mathrm{~m}$, $2 \mathrm{H}), 3.95(\mathrm{~s}, 6 \mathrm{H}), 6.40(\mathrm{dd}, J=19.1,4.7 \mathrm{~Hz}, 2 \mathrm{H}), 7.04(\mathrm{~d}, J=$ $19.1 \mathrm{~Hz}, 2 \mathrm{H}), 7.12(\mathrm{~d}, J=16.7 \mathrm{~Hz}, 2 \mathrm{H}), 7.12$ (s, $2 \mathrm{H}), 7.44(\mathrm{~d}$, $J=8.3 \mathrm{~Hz}, 4 \mathrm{H}), 7.50(\mathrm{~d}, J=16.7 \mathrm{~Hz}, 2 \mathrm{H}), 7.53(\mathrm{~d}, J=8.3 \mathrm{~Hz}$, $4 \mathrm{H}) .{ }^{13} \mathrm{C}$ NMR $\left(100 \mathrm{MHz}, \mathrm{CDCl}_{3}\right): \delta 11.3,19.0,56.5,108.7$, 121.2, 122.8, 126.2, 126.4, 128.1, 132.0, 136.9, 137.2, 146.7, 151.0. IR (KBr): $v$ 2950, 2933, 2885, 2852, 2831, 2104, 1556, 1516, 1487, $1462,1348,1205,1176,964,882,870,788,764,637 \mathrm{~cm}^{-1}$. HRMS (FAB): calcd for $\mathrm{C}_{40} \mathrm{H}_{54} \mathrm{O}_{2} \mathrm{Si}_{2}, 622.3662$; found, 622.3657 .

Polymer 4a. A mixture of $\mathbf{6}^{7}(93 \mathrm{mg}, 0.2 \mathrm{mmol}), 7 \mathbf{a}(70 \mathrm{mg}$, $0.2 \mathrm{mmol}), \mathrm{NaI}(64 \mathrm{mg})$, and $\mathrm{RhCl}\left(\mathrm{PPh}_{3}\right)_{3}(4.6 \mathrm{mg}, 0.001 \mathrm{mmol})$ in THF $(5 \mathrm{~mL})$ was refluxed under $\mathrm{N}_{2}$ for $10 \mathrm{~h}$. Methanol was added. The precipitate was collected and redissolved in THF and then precipitated again with methanol. The product was collected by filtration and washed with methanol to give polymer (122 mg, $75 \%): M_{\mathrm{n}}=9300 ; \mathrm{PDI}=2.45 .{ }^{1} \mathrm{H}$ NMR $\left(400 \mathrm{MHz}, \mathrm{CDCl}_{3}\right): \delta$ 0.30 (s, $12 \mathrm{H}), 3.61-3.69$ (m, $24 \mathrm{H}), 6.19-6.24$ (d, $2 \mathrm{H}), 6.45-$ $6.61(\mathrm{~m}, 6 \mathrm{H}), 6.82-6.90(\mathrm{~m}, 4 \mathrm{H}), 7.08(\mathrm{~s}, 2 \mathrm{H}), 7.26-7.30(\mathrm{~d}, 4$ $\mathrm{H}), 7.33-7.44(\mathrm{~m}, 8 \mathrm{H})$. IR (KBr): $v$ 3391, 2951, 2866, 1605, 1515, 1390, 1349, 1247, 1185, 1113, 986, 838, $736 \mathrm{~cm}^{-1}$. Anal. Calcd for $\mathrm{C}_{50} \mathrm{H}_{62} \mathrm{~N}_{2} \mathrm{O}_{4} \mathrm{Si}_{2}$ : C, 74.03; H, 7.70; N, 3.45. Found: C, 73.09; H, 7.32; N, 3.39.

Polymer 4b. In a manner similar to that described above, a mixture of $\mathbf{6}$ (93 mg, $0.2 \mathrm{mmol}), 7 \mathbf{b}$ (92 mg, $0.2 \mathrm{mmol}), \mathrm{NaI}(64$ $\mathrm{mg}$ ), and $\mathrm{Rh}\left(\mathrm{PPh}_{3}\right)_{3} \mathrm{Cl}(4.6 \mathrm{mg}, 0.001 \mathrm{mmol})$ was converted to $\mathbf{4 b}$ $(115 \mathrm{mg}, 62 \%): M_{\mathrm{n}}=8600 ; \mathrm{PDI}=2.27 .{ }^{1} \mathrm{H} \mathrm{NMR}(400 \mathrm{MHz}$, $\left.\mathrm{CDCl}_{3}\right): \delta 1.07-1.12(\mathrm{~m}, 28 \mathrm{H}), 3.63-3.71(\mathrm{~m}, 24 \mathrm{H}), 6.16-$ 6.20 (d, 2 H), 6.60-6.64 (d, 2 H), 6.66-6.90 (d, 4 H), 6.90-6.99 (m, 4 H), $7.11(\mathrm{~d}, 2 \mathrm{H}), 7.35-7.37(\mathrm{~d}, 4 \mathrm{H}), 7.48-7.50(\mathrm{~m}, 8 \mathrm{H})$. 
IR (KBr): v 3446, 2948, 2861, 1652, 1604, 1539, 1520, 1457, 1424, $1387,1350,1275,1229,1184,989,881,789 \mathrm{~cm}^{-1}$.

Polymer 5a. In a manner similar to that described above, a mixture of $\mathbf{8}^{7}$ ( $\left.84 \mathrm{mg}, 0.2 \mathrm{mmol}\right), \mathbf{9 a}(102 \mathrm{mg}, 0.2 \mathrm{mmol}), \mathrm{NaI}(64$ $\mathrm{mg})$, and $\mathrm{Rh}\left(\mathrm{PPh}_{3}\right)_{3} \mathrm{Cl}(4.6 \mathrm{mg}, 0.001 \mathrm{mmol})$ was converted to $\mathbf{5 a}$ $(140 \mathrm{mg}, 75 \%): M_{\mathrm{n}}=8700 ; \mathrm{PDI}=2.05 .{ }^{1} \mathrm{H}$ NMR $(400 \mathrm{MHz}$, $\left.\mathrm{CDCl}_{3}\right): \delta 0.28(\mathrm{~s}, 12 \mathrm{H}), 3.50-3.65(16 \mathrm{H}), 3.65-3.80(\mathrm{~m}, 4 \mathrm{H})$, $3.93(\mathrm{~s}, 6 \mathrm{H}), 6.20-6.30(\mathrm{~d}, 2 \mathrm{H}), 6.45-6.55(\mathrm{~d}, 2 \mathrm{H}), 6.55-6.75$ (d, $4 \mathrm{H}), 6.80-7.00(\mathrm{~m}, 4 \mathrm{H}), 7.05-7.15(\mathrm{~m}, 4 \mathrm{H}), 7.30-7.35(\mathrm{~d}$, $4 \mathrm{H}), 7.40-7.55(\mathrm{~m}, 10 \mathrm{H})$. IR (KBr): $v$ 3620, 3187, 2921, 2840, $1659,1589,1516,1250,1209,1176,1107,1033,821,674 \mathrm{~cm}^{-1}$.

Polymer 5b. In a manner similar to that described above, a mixture of $\mathbf{8}$ ( $84 \mathrm{mg}, 0.2 \mathrm{mmol}), \mathbf{9 b}(125 \mathrm{mg}, 0.2 \mathrm{mmol}), \mathrm{NaI}(64$ $\mathrm{mg})$, and $\mathrm{Rh}\left(\mathrm{PPh}_{3}\right)_{3} \mathrm{Cl}(4.6 \mathrm{mg}, 0.001 \mathrm{mmol})$ was converted to $\mathbf{5 b}$ $(125 \mathrm{mg}, 60 \%): M_{\mathrm{n}}=7500 ; \mathrm{PDI}=2.17 .{ }^{1} \mathrm{H}$ NMR $(400 \mathrm{MHz}$, $\left.\mathrm{CDCl}_{3}\right): \delta 1.05-1.20(\mathrm{~m}, 28 \mathrm{H}), 3.55-3.70(\mathrm{~m}, 16 \mathrm{H}), 3.70-$ $3.80(\mathrm{~m}, 4 \mathrm{H}), 3.95$ (s, $6 \mathrm{H}), 6.15-6.25(\mathrm{~d}, 2 \mathrm{H}), 6.45-6.55(\mathrm{~d}, 2$ H), 6.60-6.70 (d, $4 \mathrm{H}), 6.85-7.05(\mathrm{~m}, 4 \mathrm{H}), 7.05-7.15(\mathrm{~m}, 4 \mathrm{H})$, 7.30-7.40 (d, $4 \mathrm{H}), 7.45-7.60$ (m, $10 \mathrm{H})$. IR (KBr) $v$ 3436, 2950 , $2885,2856,1650,1614,1520,1458,1405,1368,1221,1185,1119$, $972,788,633 \mathrm{~cm}^{-1}$.

Time-Resolved Fluorescence Measurements. A mode-locked Ti:sapphire laser (wavelength, $750 \mathrm{~nm}$ for $\mathbf{4}, 820 \mathrm{~nm}$ for $\mathbf{5}$; repetition rate, $76 \mathrm{MHz}$; pulse width, $<200 \mathrm{fs}$ ) passed through an optical parametric amplifier. The fluorescence of sample was reflected by a grating $(150 \mathrm{~g} / \mathrm{mm}$; BLZ: $500 \mathrm{~nm})$ and detected by an optically triggered streak camera (Hamamatsu C5680) with a time resolution of about 3 ps.

STM Characterization. STM imaging of polymers $4 a$ and $\mathbf{4 b}$ was carried out with a NanoScope IIIa controller equipped with a low-current converter for experiments requiring high tunneling impedance (Veeco Metrology Group/Digital Instruments, USA). The STM probes were commercially available Pt/Ir tips (PT, Nanotips, Veeco Metrology Group/Digital Instruments, USA). To observe individual polymers, a relatively diluted solution was prepared by dissolving $1 \mu \mathrm{g} / \mathrm{mL}$ 4aor $\mathbf{4 b}$ in hexane (ca. $0.25 \mu \mathrm{M}$ ). The polymers were drop-cast onto freshly cleaved HOPG (highly orientated pyrolytic graphite, grade ZYD, Advanced Ceramics Corp.), subjected to vacuum-dry ( $\sim 30 \mathrm{~min}, 120 \mathrm{mTorr})$ to remove trace amount of solvent, and rapidly transferred to a chamber where dry $\mathrm{N}_{2}$ was purging throughout the experiments and the humidity was lower than $2 \%$. Typical imaging conditions were $0.5-1.2 \mathrm{~V}$ in bias voltage and 10 50 pA in tunneling current. The dimensions of images were calibrated by the unit cell vectors of the underlying HOPG.

Acknowledgment. This work is supported by the National Science Council and the National Taiwan University of the Republic of China.

Supporting Information Available: Figures showing ${ }^{1} \mathrm{H}$ NMR spectra of all new compounds and electrochemical properties of 7 and 9. This material is available free of charge via the Internet at http://pubs.acs.org.

\section{References and Notes}

(1) For reviews, see: (a) Jung, M. E.; Piizi, G. Chem. Rev. 2005, 105 , 1735. (b) Sammes, P. G.; Weller, D. J. Synthesis 1995, 1205. (c) Galli, C.; Mandolini, L. Eur. J. Org. Chem. 2000, 3117.
(2) For a recent review, see: (a) Toniolo, C.; Crisma, M.; Formaggio, F.; Peggion, C. Biopolymers 2001, 60, 396. (b) Bunz, U. H. F. Top. Curr. Chem. 1999, 210, 131.

(3) (a) Alder, R. W.; Maunder, C. M.; Orpen, A. G. Tetrahedron Lett. 1990, 31, 6717. (b) Alder, R. W.; Allen, P. R.; Khosravi, E. J. Chem Soc. Chem. Commun. 1994, 1235. (c) Alder, R. W.; Anderson, K. R.; Benjes, P. A.; Butts, C. P.; Koutentis, P. A.; Orpen, A. G. Chem. Commun. 1998, 309. (d) Alder, R. W.; Allen, P. R.; Hnyk, D.; Rankin, D. W. H.; Robertson, H. E.; Smart, B. A.; Gillespie, R. J.; Bytheway, I. J. Org. Chem. 1999, 64, 4226. (e) Alder, R. W.; Allen, P. R.; Anderson, K. R.; Butts, C. P.; Khosravi, E.; Martín, A.; Maunder, C. M.; Orpen, A. G.; Pourçain, C. B. St. J. Chem. Soc., Perkin Trans. 2 1998, 2083.

(4) (a) Luh, T.- Y.; Cheng, Y.- J. Chem. Commun. 2006, 45, 4669. (b) Hu, S. S.; Webber, W. P. Polym. Bull. (Berlin) 1989, 21, 133. (c) Ijadi-Maghsoodi, S.; Barton, T. J. Macromolecules 1990, 23, 4485. (d) Corriu, R. J. P.; Guerin, C.; Henner, B.; Jean, A.; Garnier, F.; Yassar, A.; Kuhlmann, T. Chem. Mater. 1990, 2, 351. (e) Ohshita, J.; Kanaya, D.; Ishikawa, M.; Koike, T.; Yamanaka, T. Macromolecules 1991, 24, 2106. (f) Wu, H. J.; Interrante, L. V. Macromolecules 1992 , 25, 1840. (g) Miao, Y.-J.; Bazan, G. C. Macromolecules 1997, 30, 7414. (h) Mori, A.; Takahisa, E.; Kajiro, H.; Nishihara, Y.; Hiyama, T. Macromolecules 2000, 33, 1115. (i) Jung, S.-H.; Kim, H. K.; Kim, S.-H.; Kim, Y. H.; Jeoung, S. C.; Kim, D. Macromolecules 2000, 33, 9277. (j) Ishikawa, M.; Hatano, T.; Hasegawa, Y.; Horio, T.; Kunai, A.; Miyai, A.; Ishida, T.; Tsukihara, T.; Yamanaka, T.; Koike, T.; Shioya, J. Organometallics 1992, 11, 1604. (k) You, Y.; An, C.-G.; Lee, D.-S.; Kim, J.-J.; Park, S. Y. J. Mater. Chem. 2006, 16, 4706. (1) West, R. J. Organomet. Chem. 1986, 300, 327. (m) Birot, M. Pillot, J.-P.;Dunoguè, J. Chem. Rev. 1995, 95, 1443. (n) Brouwer, H. J.; Krasnikov, V. V.; Hilberer, A.; Hadziioannou, G. Adv. Mater. 1996, 8, 935. (o) Ryu, M.-K.; Kim, K. D.; Lee, S. M.; Cho, S. W.; Park, J. W. Macromolecules 1998, 31, 1114. (p) Malliaras, G. G.; Herrema, J. K.; Wildeman, J.; Wieringa, R. H.; Gill, R. E.; Lampoura, S. S.; Hadziioannou, G. Adv. Mater. 1993, 5, 721. (q) Ohshita, J.; Kangai, S.; Yoshida, H.; Kunai, A.; Kajiwara, S.; Ooyama, Y.; Harima, Y. J. Organomet. Chem. 2007, 692, 801.

(5) (a) Chen, R.-M.; Chien, K.-M.; Wong, K.-T.; Jin, B.-Y.; Luh, T.-Y.; Hsu, J.-H.; Fann, W. J . Am. Chem. Soc. 1997, 119, 11321. (b) Yeh, M.-Y.; Lin, H.-C.; Lee, S.-L.; Chen, C.-h.; Lim, T.-S.; Fann, W.; Luh, T.-Y. Chem. Commun. 2007, 3459. (c) Hwu, T.-Y.; Basu, S.; Chen, R.-M.; Cheng, Y.-J.; Hsu, J.-H.; Fann, W.; Luh, T.-Y. J. Polym. Sci. Part A: Polym. Chem. 2003, 40, 2218.

(6) (a) Cheng, Y.- J.; Luh, T.- Y. Chem.-Eur. J. 2004, 10, 5361. (b) Luh, T.- Y. Pure Appl. Chem. 2005, 77, 2083. (c) Cheng, Y.- J.; Hwu, T.- Y.; Hsu, J.- H.; Luh, T.- Y. Chem. Commun. 2002, 1978.

(7) Wang, H.-W.; Cheng, Y.- J.; Chen, C.- H.; Lim, T.- S.; Fann, W.; Lin, C.- L.; Luh, T.- Y. Macromolecules 2007, 40, 2666.

(8) Cheng, Y.- J.; Liang, H.; Luh, T.- Y. Macromolecules 2003, 36, 5912.

(9) Pourtois, G.; Beljonne, D.; Cornil, J.; Ratner, M. A.; Brédas, J. L. J. Am. Chem. Soc. 2002, 124, 4436.

(10) van Walree, C. A.; Roest, M. R. P.; Schuddeboom, W.; Jenneskens, L. W.; Verhoeven, J. W.; Warman, J. M.; Kooijman, H.; Spek, A. L. J. Am. Chem. Soc. 1996, 118, 8395.

(11) The charge-transfer rate constant $k_{\mathrm{cs}}$ and the corresponding chargeseparation yield $\Phi_{\mathrm{cs}}$ were calculated according to literature methods: (a) Sandanayaka, A. S. D.; Taguri, Y.; Araki, Y.; Ishi-i, T.; Mataka, S.; Ito, O. J. Phys. Chem. B 2005, 109, 22502. (b) Hattori, S.; Ohkubo, K.; Urano, Y.; Sunahara, H.; Nagano, T.; Wada, Y.; Tkachenko, N. V.; Lemmetyinen, H.; Fukuzumi, S. J. Phys. Chem. B 2005, 109 , 15368

(12) Martín-Villamil, R.; Lafuente, A.; Rodríguez, J. G. Tetrahedron 2003, $59,1021$.

(13) Thomas, K.; Christel, N.; Gabriele, N. Chem. Ber. 1994, 127, 659. MA702197K 